\title{
Antibiotic consumption and management at Kocani General Hospital - Annual report
}

\author{
Nada Ilieva, Milena Nikolova, Donka Pankov, Maja Simonoska Crcarevska, \\ Kristina Mladenovska, Dushko Shalabalija, Ljubica Mihailova, Olga Gigopulu, \\ Marija Glavas Dodov*
}

\author{
Faculty of pharmacy, Ss. Cyril and Methodius University, Majka Tereza 47, 1000 Skopje, \\ R. North Macedonia
}

Received: April 2019; Accepted: June 2019

\begin{abstract}
The aim of the study was to get detailed insight into the antibiotic consumption trends in the three year period (2016-2018) in Kocani Hospital, to identify the most often prescribed antibiotics and to determine whether the treatment of given diagnosis was in accordance with the official guidelines. The survey covered all pediatric and infant patients admitted to the pediatric ward. Patients' data included gender, age, diagnosis, antibiotic used and doses. The majority of admitted patients were in the age group of $0-1$ (27.48\%, $25.94 \%$ and $30.77 \%$ for 2016, 2017 and 2018, accordingly) followed by age group of $1-2$ years $(20.86 \%, 22,0 \%$ and $23.83 \%$ for 2016 , 2017 and 2018, consequently) and 2-3 years (16.06\%, 16.1\% and 14.63\% for 2016, 2017 and 2018, consequently) .The most frequent diagnosis was acute tonsillitis which was determined in $\sim 21 \%$ of patients, pneumonia without complications in $\sim 18 \%$ and acute bronchitis in $\sim 16 \%$ of patients in the period $2016-2018$. Results from conducted survey identified high prescription rate and use of antibiotics predominantly ceftriaxone $(82.58 \%, 81.05 \%$ and $50.85 \%$ in 2016,2017 and 2018, respectively) contrary to official recommendations and evidences based on clinical data for treatment of the diagnoses in question. So, it is foreseeable to conclude that there is urgent need for restrictive and educational measures i.e. to strength the surveillance and monitoring of antibiotic prescription and usage and hence to promote awareness for rational use of antibiotics on all health-care levels.
\end{abstract}

Keywords: antibiotic prescription, antibiotic consumption, pediatric wards, annual report

\section{Introduction}

Antibiotics also known as antimicrobial drugs are commonly used for treatment of bacterial infections. Antibiotics are one of the most powerful medicines that have saved great number of people's life, despite the fact that in Greek, the translation of their name means anti bios (anti life). They inhibit or prevent the growth of bacteria, fungi and some parasites, but they cannot kill viruses. People misused antibiotics during the $20^{\text {th }}$ century and this irrational consumption of antibiotics has resulted

*magl@ff.ukim.edu.mk with occurrence of so called "resistant bacteria". Antimicrobial resistance occurs when bacteria and other microbes adapt and become less responsive to treatment. The rapid rise and replication of antimicrobial resistant organisms worldwide is a problem of huge dimensions. The antimicrobial resistance causes about 700,000 deaths annually around the world, and each country is potentially affected. The figure can rise to 10 million till 2051. The root causes of this problem are multifactorial. The emergence of antibiotic resistance is highly related to their inadequate use (Arnold et al., 2011; Laxminarayan et al., 2013; Leuthaner et al., 2013). Studies showed that 
$30-60 \%$ of the prescribed antibiotics in the hospital sector are unnecessary, inadequate, or suboptimal (Bergmans et al., 1997; Kollef, 2001; Kollef and Fraser, 2001; Roberts et al., 2011).

Prescribing antibiotics and antibiotics misuse, undoubtedly contribute to the growth of antibiotic resistant bacteria. Epidemiological studies demonstrate direct dependence between antibiotics consumption and the emergence and replication of the resistant hospital bacteria. The optimal use of antibiotics is crucial in the healthcare setting, especially in the era when antibiotic resistance increases and there is a lack of new antimicrobial development (Arnold et al., 2011; Laxminarayan et al., 2013; Leuthaner et al., 2013). Providing reliable and comparable national data about the consumption of antibiotics is a prerequisite for understanding of the epidemiology of antibiotic resistance in Europe since their inadequate use is one of the main factors responsible for resistance to antibiotics (ArnoldLefevre et al., 2013; Goldman et al., 1996; Kollef and Fraser, 2001; Landman et al., 2002; Lipsitch et al., 2000; MacDougall and Polk, 2006; Malhota-Kumar et al., 2007; McGowan, 1983; Paterson, 2006; Ricel, 2008; Shalaes et al., 1997; Sieve et al., 2013; Thomas et al., 1998; Zillich et al., 2006).

Having in mind previous, the aim of the study was to analyze the antibiotic consumption trends in the three year period (2016-2018) in Kocani Hospital, to identify the most often prescribed antibiotics and to determine whether the treatment of given diagnosis was in accordance with the official guidelines.

\section{Materials and methods}

The retrospective survey for prescribing and consuming antibiotics for the period 2016-2018 (JanuaryDecember) was conducted in May, 2019. The survey covered all pediatric and infant patients admitted to the pediatric ward. Patients' data included gender, age, diagnosis, antibiotic used and doses. The quantity of given antibiotic as treatment and prophylaxis was coded as a daily dose - DDD for 1 or more days of prophylactic treatment. Data were collected from software program "Moj termin" (My term) and official medical records from the Kocani Hospital database. The data covered all hospitalized pediatric patients in the above mentioned period. However, it has to be emphasized that all data were available as group data, and were not collected per patient admitted in pediatric ward of Kocani Hospital.

Obtained data were tabulated in Microsoft Excel ${ }^{\circledR}$ (Microsoft Corp. Redmond, WA, USA) and were computed and consequently evaluated using statistical software STATGRAPHICS Centurion XVI evaluation (StatPoint technologies Inc., USA).

Table 1. Detailed data related to gender and age of patients admitted in Kocani Hospital pediatric ward for period 20162018 year

\begin{tabular}{ccccccc}
\hline \hline & \multicolumn{2}{c}{2016} & \multicolumn{2}{c}{2017} & \multicolumn{2}{c}{2018} \\
age & male & female & male & female & male & female \\
\hline $0-1$ & 78 & 88 & 75 & 70 & 73 & 91 \\
$1-2$ & 67 & 59 & 64 & 59 & 58 & 69 \\
$2-3$ & 57 & 40 & 48 & 42 & 28 & 50 \\
$3-4$ & 25 & 22 & 23 & 27 & 20 & 24 \\
$4-5$ & 17 & 12 & 14 & 13 & 8 & 14 \\
$5-6$ & 14 & 16 & 12 & 8 & 10 & 12 \\
$6-7$ & 7 & 10 & 6 & 9 & 4 & 9 \\
$7-8$ & 15 & 9 & 13 & 8 & 11 & 10 \\
$8-9$ & 8 & 4 & 9 & 6 & 2 & 2 \\
$9-10$ & 7 & 8 & 6 & 7 & 5 & 6 \\
$10-11$ & 3 & 4 & 8 & 3 & 5 & 2 \\
$11-12$ & 8 & 3 & 5 & 2 & 6 & 3 \\
$12-13$ & 2 & 5 & 2 & 4 & 1 & 4 \\
$13-14$ & 4 & 2 & 3 & 3 & 2 & 1 \\
$14-15$ & 3 & 0 & 3 & 1 & 1 & 0 \\
$15-16$ & 4 & 0 & 2 & 1 & 2 & 0 \\
$16-17$ & 2 & 1 & 3 & 0 & 0 & 0 \\
\hline Subtotal & 321 & 283 & 296 & 263 & 236 & 297 \\
Total & \multicolumn{2}{r}{604} & 559 & & 533 \\
\hline
\end{tabular}


Table 2. Number of patients by diagnosis admitted in pediatric ward in Kocani Hospital in the period 2016-2018 year

\begin{tabular}{|c|c|c|c|c|c|c|c|c|c|c|}
\hline & & & 2016 & & & 2017 & & & 2018 & \\
\hline & ICD-10-CM code & female & male & total & female & male & total & female & male & total \\
\hline 1 & J 00 Acute nasopharyngitis [common cold] & 9 & 8 & 17 & 7 & 4 & 11 & 3 & 10 & 13 \\
\hline 2 & $\mathrm{~J} 02$ Acute pharyngitis & 31 & 17 & 48 & 21 & 24 & 45 & 9 & 30 & 39 \\
\hline 3 & J 03.9 Acute tonsillitis, unspecified & 54 & 73 & 127 & 60 & 57 & 117 & 49 & 58 & 107 \\
\hline 4 & J 04.0 Acute laryngitis & 7 & 6 & 13 & 5 & 1 & 6 & 1 & 4 & 5 \\
\hline 5 & J 18.0 Bronchopneumonia, unspecified organism & 59 & 52 & 111 & 53 & 47 & 100 & 56 & 42 & 98 \\
\hline 6 & J 18.9 Pneumonia, unspecified organism & 18 & 9 & 27 & 9 & 11 & 20 & 10 & 12 & 22 \\
\hline 7 & J 20.9 Acute bronchitis, unspecified & 47 & 49 & 96 & 49 & 44 & 93 & 32 & 56 & 88 \\
\hline 8 & $\begin{array}{l}\mathrm{J} 21.8 \text { Acute bronchiolitis due to other specified } \\
\text { organisms }\end{array}$ & & 4 & 4 & & 1 & 1 & & 1 & 1 \\
\hline 9 & J 21.9 Acute bronchiolitis, unspecified & 28 & 25 & 53 & 28 & 16 & 44 & 19 & 28 & 47 \\
\hline 10 & $\begin{array}{l}\mathrm{J} 40 \text { Bronchitis, not specified as acute or chronic } \\
\text { (asthma) }\end{array}$ & & 2 & 2 & & 3 & 3 & & 1 & 1 \\
\hline 11 & $\begin{array}{l}\text { J } 44.1 \text { Chronic obstructive pulmonary disease with } \\
\text { (acute) exacerbation }\end{array}$ & 1 & 4 & 5 & & 2 & 2 & & 1 & 1 \\
\hline 12 & N 39.0 Acute cystitis & 4 & 2 & 6 & 9 & 1 & 10 & 7 & 1 & 8 \\
\hline 13 & N 39.9 Disorder of urinary system, unspecified & 2 & & 2 & 2 & & 2 & 1 & & 1 \\
\hline 14 & A 08.0 Rotaviral enteritis & 3 & 1 & 4 & 7 & 2 & 9 & 3 & 3 & 6 \\
\hline 15 & A 09 Infectious gastroenteritis and colitis, unspecified & 4 & 2 & 6 & 2 & 3 & 5 & 4 & 3 & 7 \\
\hline 16 & D 69.0 Allergic purpura & 1 & 1 & 2 & 1 & & 1 & 1 & 1 & 2 \\
\hline 17 & B 34.9 Viral infection, unspecified & & 2 & 2 & & 1 & 1 & & 1 & 1 \\
\hline 18 & F 31.7 Bipolar disorder, currently in remission & 1 & & 1 & 2 & & 2 & 1 & & 1 \\
\hline 19 & G 40.90 Epilepsy, unspecified, not intractable & 2 & 1 & 3 & 1 & & 1 & 1 & & 1 \\
\hline 20 & G 80.03 Athetoid cerebral paralysis & 1 & & 1 & & & 0 & 1 & & 1 \\
\hline 21 & H 65.9 Unspecified nonsuppurative otitis media & 1 & 1 & 2 & 2 & 3 & 5 & 1 & 2 & 3 \\
\hline 22 & I 47.9 Paroxysmal tachycardia, unspecified & 2 & & 2 & & & 0 & 1 & & 1 \\
\hline 23 & K 12.1 Other forms of stomatitis & & 1 & 1 & & 1 & 1 & & 1 & 1 \\
\hline 24 & K 29.9 Gastroduodenitis, unspecified & 1 & & 1 & 2 & & 2 & 1 & & 1 \\
\hline 25 & $\begin{array}{l}\text { K } 52.9 \text { No infective gastroenteritis and colitis, } \\
\text { unspecified }\end{array}$ & 10 & 8 & 18 & 6 & 12 & 18 & 10 & 11 & 21 \\
\hline 26 & K 56.0 Paralytic ileus & & 1 & 1 & & 1 & 1 & & 1 & 1 \\
\hline 27 & L 04.0 Acute lymphadenitis of face, head and neck & & 3 & 3 & & 1 & 1 & & 2 & 2 \\
\hline 28 & L 20.9 Atopic dermatitis, unspecified & & 2 & 2 & 3 & & 3 & & 1 & 1 \\
\hline 29 & L 23.9 Allergic contact dermatitis, unspecified cause & & 3 & 3 & 3 & & 3 & & 4 & 4 \\
\hline 30 & $\begin{array}{l}\text { L } 27.9 \text { Dermatitis due to unspecified substance taken } \\
\text { internally }\end{array}$ & & 1 & 1 & & 2 & 2 & & 1 & 1 \\
\hline
\end{tabular}




\begin{tabular}{|c|c|c|c|c|c|c|c|c|c|c|}
\hline 31 & L 50.0 Allergic urticaria & & 2 & 2 & & 1 & 1 & & 1 & 1 \\
\hline 32 & L 50.9 Urticaria, unspecified & 5 & & 5 & 4 & 4 & 8 & & 7 & 7 \\
\hline 33 & M 60.9 Myositis, unspecified & & 1 & 1 & & 1 & 1 & & 1 & 1 \\
\hline 34 & P 39 Other infections specific to the perinatal period & 3 & & 3 & & 2 & 2 & 4 & & 4 \\
\hline 35 & R 10.0 Acute abdomen & 1 & & 1 & & 3 & 3 & & 1 & 1 \\
\hline 36 & R 10.9 Unspecified abdominal pain & 1 & & 1 & & 1 & 1 & & 2 & 2 \\
\hline 37 & R 11 Nausea and vomiting & 21 & 2 & 23 & 20 & 10 & 30 & 20 & 8 & 28 \\
\hline 38 & R 55 Syncope and collapse & 1 & & 1 & & 2 & 2 & & 1 & 1 \\
\hline 39 & R 56.9 Unspecified convulsions & 2 & & 2 & & 1 & 1 & 1 & & 1 \\
\hline 40 & $\begin{array}{l}\text { T } 39.9 \text { Poisoning by, adverse effect of and under } \\
\text { dosing of unspecified no opioid analgesic, antipyretic } \\
\text { and antirheumatic }\end{array}$ & 1 & & 1 & & 1 & 1 & & 1 & 1 \\
\hline & Total & 321 & 283 & 604 & 296 & 263 & 559 & 236 & 297 & 533 \\
\hline
\end{tabular}

\section{Results and discussion}

The overall number of patients admitted at the pediatric ward of Kocani Hospital in the study period 2016-2018 was 1696. Detailed data related to gender and age are given in Table 1.

One-way ANOVA $(p<0.05)$ indicated that there was no statistical significant difference between total number of patients, as well as male and female patients in each year of studied period. However, it pointed that there is statistical difference between age groups. From results presented in Table 1, it can be clearly seen that the majority of admitted patients were in the age group of $0-1$ (27.48\%, 25.94\% and 30.77\% for 2016, 2017 and 2018, accordingly) followed by age group of $1-2$ years $(20.86 \%$, $22.0 \%$ and $23.83 \%$ for 2016, 2017 and 2018, consequently) and $2-3$ years $(16.06 \%, 16.1 \%$ and $14.63 \%$ for 2016, 2017 and 2018, consequently). Overall results indicated that the number of patients decreased with age.

From detailed results presented in Table 2, it can be seen that the most frequent diagnosis was acute tonsillitis (code J03.9 according to ICD-10-CM (International Classification of Diseases, Tenth Revision, Clinical Modification)) which was determined in $21.03 \%, 20.93 \%$ and $20.08 \%$ of patients in 2016, 2017 and 2018, accordingly, followed by pneumonia without complications (ICD-10-CM code J18.0) in $18.38 \%$, $17.89 \%$ and $18.39 \%$ and acute bronchitis (ICD-10-CM code $\mathrm{J} 20.9$ ) in $15.89 \%, 16.64 \%$ and $16.51 \%$ of patients in 2016, 2017 and 2018, consequently.

Total quantity of antibiotics ordered from hospital pharmacy and used (2016-2018) in pediatric ward of Kocani Hospital is given in Table 3. Results pointed that $\sim 97 \%$ of ordered antibiotics were used. The most common used antibiotic was ceftriaxone with a share of $82.58 \%$, $81.05 \%$ and $50.85 \%$ in 2016, 2017 and 2018 year, accordingly. The lower share of ceftriaxone in 2018 is related to the significant increase of ampicillin usage compared to previous years $(32.58 \%$ in 2018 vs $1.04 \%$ in 2017 and $0 \%$ in 2016 year). In accordance were the findings of Quaak et al. (2018) for the antibiotic use in secondary care urban teaching hospital in Rotterdam, the Netherlands. Namely, in the surveyed period 2010-2015 most commonly used antibiotics were cefotaxime and ceftriaxone, and hence their use showed a significant decrease during years due to the increase of amoxicillin and amoxicillin/clavulanic acid usage. The situation was similar in pediatric wards in hospitals in Latvia where a one-day cross-sectional point prevalence survey conducted in November, 2012 indicated that the thirdgeneration cephalosporins were among the mostly used antibiotic groups for pediatric patients with share of cefazolin and ceftriaxone of $24.2 \%$ and $21 \%$, respectively (Sviestina and Mozgis, 2014). In the study of Porta et al. (2012), conducted in 2009 in UK, Italy and Greece, 37\% of all antibiotics were penicillin b-lactam antibacterials with type of b-lactam varied between hospitals. In UK hospitals use of co-amoxiclav prevailed, while in Italy and Greece hospitals ceftriaxone/cefotaxime and cefuroxime/ceftriaxone, respectively were dominantly used. Such high share of ceftriaxone use might be explained with social acceptance of the common believe that intravenous antibiotics are "stronger" than oral ones (Sviestina and Mozgis, 2014).

Usage of antibiotics per given diagnosis is presented in Tables 4, 5 and 6 for 2016, 2017 and 2018, accordingly. 
Table 3. Quantity of ordered and used antibiotics in pediatric ward of Kocani Hospital 2016-2018 year

\begin{tabular}{lcccccc}
\hline \hline & \multicolumn{2}{c}{2016} & \multicolumn{2}{c}{2017} & \multicolumn{2}{c}{2018} \\
& ordered & used & ordered & used & ordered & used \\
\hline Amp. Ampicillin á $1.0 \mathrm{~g}$ & 0 & 0 & 60 & 27 & 1650 & 1644 \\
Amp. Ceftriaxone á $1.0 \mathrm{~g}$ & 2080 & 2029 & 2129 & 2113 & 2640 & 2566 \\
Sir. Cephalexin á $250 \mathrm{mg} / 5 \mathrm{ml}$ & 6 & 5 & 1 & 1 & 2 & 0 \\
Caps. Cephalexin á $500 \mathrm{mg}$ & 48 & 48 & 70 & 60 & 192 & 192 \\
Sir. Amoxicillin + clavulanic acid á & 37 & 35 & 65 & 59 & 55 & 53 \\
4oo mg/ 57 mg/5 ml & & & & & & \\
Sir. Cefaclor á 25o mg/5 ml & 19 & 15 & 30 & 30 & 27 & 25 \\
Amp. Cefotaxime á 50o mg & 270 & 270 & 220 & 210 & 325 & 306 \\
Amp. Amikacin á 5oo mg & 30 & 30 & 73 & 64 & 130 & 130 \\
Amp. Gentamicin á 40 mg/2 ml & 10 & 0 & 50 & 43 & 80 & 80 \\
Amp. Gentamicin á 20 mg/2 ml & 30 & 25 & 5 & 0 & 50 & 50 \\
\hline
\end{tabular}

Having in mind that most commonly in the period 2016-2018 patients admitted in pediatric ward of Kocani Hospital were diagnosed with acute tonsillitis, pneumonia without a complications and acute bronchitis it is normally to expect that most of the prescribed DDD of antibiotics were related to these conditions. $36.55 \%$, $39.56 \%$ and $23.6 \%$ of all DDD of prescribed antibiotics in 2016, 2017 and 2018 were related to pneumonia without complications and in case of acute tonsillitis $18.19 \%$, $19.33 \%$ and $23.58 \%$ and acute bronchitis $15.06 \%, 11.2 \%$ and $14.36 \%$ of all DDD of antibiotics were prescribed in 2016, 2017 and 2018, accordingly. Respiratory infections were also most common diagnosis in pediatric wards in hospitals in Latvia, where $34.7 \%$ and $13.9 \%$ of pediatric patients were diagnosed with lower and upper respiratory tract infections (Sviestina and Mozgis, 2014). However, in the study of Patel et al. (2012) in UK, Italy and Greece hospitals, antibiotics were most commonly used for surgical prophylaxis $(21 \%)$ with differences between surveyed hospitals (2\% and $31 \%$ in two UK hospitals (Center 1 and 2), and $18 \%$ in Italy and $31 \%$ in Greece surveyed hospital. In UK Center 1 and Italy hospital the main indication for antibiotic treatment was lower respiratory tract infection in $17 \%$ and $37 \%$ of children, respectively.

It can be seen that patients diagnosed with Acute tonsillitis (ICD-10-CM code J03.9) in 2016 and 2017 were most frequently treated with Amp. Ceftriaxone á 1.0 g $(93.06 \%$ in 2016 and $90.87 \%$ in 2017 of DDD of prescribed antibiotics for the J03.9). However, in 2018 only $37.14 \%$ of patients were treated with this antibiotic vs $58.54 \%$ which were treated with Amp. Ampicillin á 1.0 $\mathrm{g}$. The treatment was prescribed empirically in all cases (no microbiology analysis were required and conducted). According to guidelines for medical care of tonsillitis and pharyngitis in pediatric population issued by Ministry of healthcare of Republic of North Macedonia (http://zdravstvo.gov.mk/wp-content/uploads/2015/08/

Tonzilitis-i-faringitis-kaj-deca1.pdf) if infection is caused by group A streptococci it should be treated with penicillin $70 \mathrm{mg} / \mathrm{kg}$ daily $(100,000 \mathrm{~d} / \mathrm{kg} / 24 \mathrm{~h})$, or in patients allergic to penicillin with cephalexin 50 $\mathrm{mg} / \mathrm{kg} / 24 \mathrm{~h}$, in two doses for 10 days. Short-term cephalosporin therapy (2 to 6 days) may be effective but is associated with more side effects. Shorter therapy may be used if there is difficulty in prolonging a child's antibiotic treatment. Macrolides are used to treat tonsillitis only in patients with penicillin or cephalosporin allergy.

Patients diagnosed with pneumonia without complications (ICD-10-CM code J18.0) were treated with Amp. Ceftriaxone á $1.0 \mathrm{~g}$ in $79.37 \%, 81.88 \%$ and $74.76 \%$ of DDD of prescribed antibiotics in 2016, 2017 and 2018 year, accordingly. Similar was the situation for treatment of bronchopneumonia in Pediatric Clinic in Sarajevo where first (cefazolin in $40.4 \%$ of patients) and third generation of cephalosporins (31.7\% of patients with most often used ceftazidime followed by ceftriaxone and cefixime) and penicillin antibiotics (25\% of patients) were commonly used (Zec et al., 2016). According to the guidelines for medical care of pneumonia in childhood issued by the Ministry of healthcare of Republic of North Macedonia (http://zdravstvo.gov.mk/wp-content/uploads/ 2015/08/Pnevmonii-vo-detstvoto.pdf) medicine of choice in preschool children as first-line therapy is amoxicillin $40-50 \mathrm{mg} / \mathrm{kg} /$ day in 3 doses for 7 days. The same recommendations are for treatment of pneumonia in school children, but having in mind that Mycoplasma and Chlamydia infections are very often in this group it might be considered that the treatment may be based on 
Table 4. Usage of antibiotic per given diagnosis in pediatric ward of Kocani Hospital in 2016 year

\begin{tabular}{|c|c|c|c|c|c|c|c|c|c|c|c|}
\hline & ICD-10-CM code & $\begin{array}{l}\text { Amp. } \\
\text { Ampicillin } \\
\text { á } 1.0 \mathrm{~g}\end{array}$ & $\begin{array}{l}\text { Amp. } \\
\text { Ceftriaxone } \\
\text { á } 1.0 \mathrm{~g}\end{array}$ & $\begin{array}{c}\text { Sir. } \\
\text { Cefalexine á } \\
250 \mathrm{mg} / 5 \mathrm{ml}\end{array}$ & $\begin{array}{c}\text { Caps. } \\
\text { Cefalexine } \\
\text { á } 500 \mathrm{mg}\end{array}$ & $\begin{array}{c}\text { Sir. } \\
\text { Amoksicilline } \\
+ \\
\text { clavulonic acid á } \\
400 \mathrm{mg} / 57 \mathrm{mg} / 5 \mathrm{ml}\end{array}$ & $\begin{array}{c}\text { Sir. } \\
\text { Cefaclor á } \\
250 \mathrm{mg} / 5 \mathrm{ml}\end{array}$ & $\begin{array}{c}\text { Amp. } \\
\text { Cefotaxim } \\
\text { á } 500 \mathrm{mg}\end{array}$ & $\begin{array}{c}\text { Amp. } \\
\text { Amikacin } \\
\text { á } 500 \mathrm{mg}\end{array}$ & $\begin{array}{c}\text { Amp. } \\
\text { Gentamicin } \\
\text { á } \\
20 \mathrm{mg} / 2 \mathrm{ml}\end{array}$ & $\begin{array}{c}\text { Amp. } \\
\text { Gentamicin } \\
\text { á } \\
40 \mathrm{mg} / 2 \mathrm{ml}\end{array}$ \\
\hline 1 & $\begin{array}{l}\text { J } 00 \text { Acute nasopharyngitis } \\
\text { [common cold] }\end{array}$ & & 37 & & & & & & & & \\
\hline 2 & $\mathrm{~J} 02$ Acute pharyngitis & & 223 & 5 & 16 & & & & & & \\
\hline 3 & J 03.9 Acute tonsillitis, unspecified & & 416 & & 16 & 7 & 8 & & & & \\
\hline 4 & J 04.0 Acute laryngitis & & 40 & & & & 3 & & & & \\
\hline 5 & $\begin{array}{l}\text { J } 18.0 \text { Bronchopneumonia, } \\
\text { unspecified organism }\end{array}$ & & 746 & & 16 & & & 136 & & & \\
\hline 6 & $\begin{array}{l}\text { J } 18.9 \text { Pneumonia, unspecified } \\
\text { organism }\end{array}$ & & 227 & & & & 1 & 28 & 30 & & \\
\hline 7 & $\begin{array}{l}\text { J } 20.9 \text { Acute bronchitis, } \\
\text { unspecified }\end{array}$ & & 214 & & & 25 & & 106 & & 25 & \\
\hline 8 & $\begin{array}{l}\text { J } 21.8 \text { Acute bronchiolitis due to } \\
\text { other specified organisms }\end{array}$ & & 8 & & & 2 & & & & & \\
\hline 9 & $\begin{array}{l}\text { J } 21.9 \text { Acute bronchiolitis, } \\
\text { unspecified }\end{array}$ & & 74 & & & & & & & & \\
\hline 10 & $\begin{array}{l}\mathrm{J} 40 \text { Bronchitis, not specified as } \\
\text { acute or chronic (asthma) }\end{array}$ & & 4 & & & & & & & & \\
\hline 11 & N 39.0 Acute cystitis & & 16 & & & & & & & & \\
\hline 12 & $\begin{array}{l}\text { N } 39.9 \text { Disorder of urinary system, } \\
\text { unspecified }\end{array}$ & & 4 & & & & & & & & \\
\hline 13 & $\begin{array}{l}\text { H } 65.9 \text { Unspecified } \\
\text { nonsuppurative otitis media }\end{array}$ & & 20 & & & 1 & 3 & & & & \\
\hline & Total & 0 & 2029 & 5 & 48 & 35 & 15 & 270 & 30 & 25 & 0 \\
\hline
\end{tabular}


Table 5. Usage of antibiotic per given diagnosis in pediatric ward of Kocani Hospital in 2017 year

\begin{tabular}{|c|c|c|c|c|c|c|c|c|c|c|c|}
\hline & ICD-10-CM code & $\begin{array}{c}\text { Amp. } \\
\text { Ampicillin } \\
\text { á } 1.0 \mathrm{~g}\end{array}$ & $\begin{array}{l}\text { Amp. } \\
\text { Ceftriaxone } \\
\text { á } 1.0 \mathrm{~g}\end{array}$ & $\begin{array}{c}\text { Sir. } \\
\text { Cefalexine á } \\
250 \mathrm{mg} / 5 \mathrm{ml}\end{array}$ & $\begin{array}{c}\text { Caps. } \\
\text { Cefalexine } \\
\text { á } 500 \mathrm{mg}\end{array}$ & $\begin{array}{c}\text { Sir. } \\
\text { Amoksicilline } \\
+ \\
\text { clavulonic acid } \\
\text { á } \\
400 \mathrm{mg} / 57 \mathrm{mg} / 5 \mathrm{ml}\end{array}$ & $\begin{array}{c}\text { Sir. } \\
\text { Cefaclor á } \\
250 \mathrm{mg} / 5 \mathrm{ml}\end{array}$ & $\begin{array}{c}\text { Amp. } \\
\text { Cefotaxim } \\
\text { á } 500 \mathrm{mg}\end{array}$ & $\begin{array}{c}\text { Amp. } \\
\text { Amikacin } \\
\text { á } 500 \mathrm{mg}\end{array}$ & $\begin{array}{c}\text { Amp. } \\
\text { Gentamicin } \\
\text { á } \\
20 \mathrm{mg} / 2 \mathrm{ml}\end{array}$ & $\begin{array}{c}\text { Amp. } \\
\text { Gentamicin } \\
\text { á } \\
40 \mathrm{mg} / 2 \mathrm{ml}\end{array}$ \\
\hline 1 & $\begin{array}{l}\text { J 00 Acute nasopharyngitis } \\
\text { [common cold] }\end{array}$ & & 40 & & 16 & & & & & & \\
\hline 2 & $\mathrm{~J} 02$ Acute pharyngitis & 10 & 236 & & 16 & & & & & & \\
\hline 3 & $\begin{array}{l}\text { J } 03.9 \text { Acute tonsillitis, } \\
\text { unspecified }\end{array}$ & 17 & 45 & & 10 & 10 & 9 & & & & \\
\hline 4 & J 04.0 Acute laryngitis & & 40 & & & & 1 & & & & \\
\hline 5 & $\begin{array}{l}\text { J } 18.0 \text { Bronchopneumonia, } \\
\text { unspecified organism }\end{array}$ & & 845 & & 18 & & & 119 & 50 & & \\
\hline 6 & $\begin{array}{l}\mathrm{J} 18.9 \text { Pneumonia, unspecified } \\
\text { organism }\end{array}$ & & 148 & & & & 9 & 36 & 14 & & \\
\hline 7 & $\begin{array}{l}\text { J } 20.9 \text { Acute bronchitis, } \\
\text { unspecified }\end{array}$ & & 196 & & & 41 & & 55 & & & \\
\hline 8 & $\begin{array}{l}\text { J } 21.8 \text { Acute bronchiolitis due to } \\
\text { other specified organisms }\end{array}$ & & 5 & & & 4 & & & & & \\
\hline 9 & $\begin{array}{l}\text { J } 21.9 \text { Acute bronchiolitis, } \\
\text { unspecified }\end{array}$ & & 65 & & & & & & & & 43 \\
\hline 10 & $\begin{array}{l}\mathrm{J} 40 \text { Bronchitis, not specified as } \\
\text { acute or chronic (asthma) }\end{array}$ & & 12 & 1 & & & & & & & \\
\hline 11 & N 39.0 Acute cystitis & & 38 & & & & & & & & \\
\hline 12 & $\begin{array}{l}\text { N } 39.9 \text { Disorder of urinary } \\
\text { system, unspecified }\end{array}$ & & 6 & & & & & & & & \\
\hline \multirow[t]{2}{*}{13} & $\begin{array}{l}\text { H } 65.9 \text { Unspecified } \\
\text { nonsuppurative otitis media }\end{array}$ & & 24 & & & 4 & 11 & & & & \\
\hline & Total & 27 & 2113 & 1 & 60 & 59 & 30 & 210 & 64 & 0 & 43 \\
\hline
\end{tabular}


Table 6. Usage of antibiotic per given diagnosis in pediatric ward of Kocani Hospital in 2018 year

\begin{tabular}{|c|c|c|c|c|c|c|c|c|c|c|c|}
\hline & ICD-10-CM code & $\begin{array}{c}\text { Amp. } \\
\text { Ampicillin } \\
\dot{a} \\
1.0 \mathrm{~g}\end{array}$ & $\begin{array}{c}\text { Amp. } \\
\text { Ceftriaxone } \\
\text { á } \\
1.0 \mathrm{~g}\end{array}$ & $\begin{array}{c}\text { Sir. } \\
\text { Cefalexine } \\
\text { á } \\
250 \mathrm{mg} / 5 \\
\mathrm{ml}\end{array}$ & $\begin{array}{c}\text { Caps. } \\
\text { Cefalexine } \\
\text { á } \\
500 \mathrm{mg}\end{array}$ & $\begin{array}{c}\text { Sir. } \\
\text { Amoksicilline } \\
+ \\
\text { clavulonic acid } \\
\text { á } \\
400 \mathrm{mg} / 57 \mathrm{mg} / 5 \mathrm{ml}\end{array}$ & $\begin{array}{c}\text { Sir. } \\
\text { Cefaclor } \\
\text { á } \\
250 \mathrm{mg} / 5 \mathrm{ml}\end{array}$ & $\begin{array}{c}\text { Amp. } \\
\text { Cefotaxim } \\
\dot{a} \\
500 \mathrm{mg}\end{array}$ & $\begin{array}{c}\text { Amp. } \\
\text { Amikacin } \\
\text { á } \\
500 \mathrm{mg}\end{array}$ & $\begin{array}{c}\text { Amp. } \\
\text { Gentamicin } \\
\text { á } \\
20 \mathrm{mg} / 2 \mathrm{ml}\end{array}$ & $\begin{array}{c}\text { Amp. } \\
\text { Gentamicin } \\
\dot{a} \\
40 \mathrm{mg} / 2 \mathrm{ml}\end{array}$ \\
\hline 1 & $\begin{array}{l}\text { J } 00 \text { Acute nasopharyngitis } \\
\text { [common cold] }\end{array}$ & 304 & 50 & 32 & & & & & & & 50 \\
\hline 2 & $\mathrm{~J} 02$ Acute pharyngitis & 428 & 260 & 32 & & & & & & & 260 \\
\hline 3 & J 03.9 Acute tonsillitis, unspecified & 692 & 439 & 32 & 10 & 9 & & & & & 439 \\
\hline 4 & J 04.0 Acute laryngitis & 220 & 40 & & & 2 & & & & & 40 \\
\hline 5 & $\begin{array}{l}\text { J } 18.0 \text { Bronchopneumonia, } \\
\text { unspecified organism }\end{array}$ & & 883 & 96 & & & 124 & 80 & & & 883 \\
\hline 6 & $\begin{array}{l}\text { J } 18.9 \text { Pneumonia, unspecified } \\
\text { organism }\end{array}$ & & 220 & & & 10 & 64 & 50 & & & 220 \\
\hline 7 & $\begin{array}{l}\text { J } 20.9 \text { Acute bronchitis, } \\
\text { unspecified }\end{array}$ & & 368 & & 40 & & 118 & & 50 & & 368 \\
\hline 8 & $\begin{array}{l}\mathrm{J} 21.8 \text { Acute bronchiolitis due to } \\
\text { other specified organisms }\end{array}$ & & 10 & & 2 & & & & & & 10 \\
\hline 9 & $\begin{array}{l}\text { J } 21.9 \text { Acute bronchiolitis, } \\
\text { unspecified }\end{array}$ & & 178 & & & & & & & 80 & 178 \\
\hline 10 & $\begin{array}{l}\text { J } 40 \text { Bronchitis, not specified as } \\
\text { acute or chronic (asthma) }\end{array}$ & & 10 & & & & & & & & 10 \\
\hline 11 & N 39.0 Acute cystitis & & 68 & & & & & & & & 68 \\
\hline 12 & $\begin{array}{l}\text { N } 39.9 \text { Disorder of urinary system, } \\
\text { unspecified }\end{array}$ & & 12 & & & & & & & & 12 \\
\hline 13 & $\begin{array}{l}\text { H } 65.9 \text { Unspecified } \\
\text { nonsuppurative otitis media }\end{array}$ & & 28 & & 1 & 4 & & & & & 28 \\
\hline & Total & 1644 & 2566 & 192 & 53 & 25 & 306 & 130 & 50 & 80 & 2566 \\
\hline
\end{tabular}


doxycycline (children older than 8 years, $200 \mathrm{mg}$ as single dose in the first day, followed by $100 \mathrm{mg}$ once a day during the next days). These guidelines are in accordance with recommendations published in Cochrane Database Systematic Reviews by Lodha et al. (2013) where amoxicillin as first-line therapy should be used, but with additional possibility to use cefpodoxime and cefuroxime as second-line therapies. Also, concomitant are recommendations of World Health Organization (Tong, 2013; WHO, 2012) for very severe pneumonia where parenteral ampicillin (or penicillin) and gentamicin are recommended as a first line treatment, while ceftriaxone should be used as a second line treatment when the first line treatment fails.

Patients diagnosed with acute bronchitis (ICD-10-CM code J20.9) were treated with Amp. Ceftriaxone á $1.0 \mathrm{~g}$ in $57.84 \%, 67.12 \%$ and $63.89 \%$ of DDD of prescribed antibiotics in 2016, 2017 and 2018 year, accordingly. Amp. Cefotaxime á $500 \mathrm{mg}$ were used in $28.65 \%, 18.84 \%$ and $20.49 \%$ of DDD of prescribed antibiotics in 2016, 2017 and 2018 year, accordingly. According to the guidelines for medical care of light form of respiratory pathways obstruction in children, issued by the Ministry of healthcare of Republic of North Macedonia (http://zdravstvo.gov.mk/wp-content/uploads/2015/08/ Tretman-na-opstruktiven-bronhitis-i-akutna-astma.pdf) inhalation of salbutamol using metered-dose inhalers or nebulizer is first choice for treatment. Medium severe obstruction should be treated with repetitive application of salbutamol with spacer or nebulizer with $100 \%$ oxygen supplementation. Also, depending from symptoms systematic corticosteroid might be considered. Similar are recommendations for treatment of repetitive or prolonged obstruction as well as severe obstruction. In the case of severe obstruction additionally, use of anticholinergic such as ipratropium bromide is suggested. Antibiotic use is indicated in treatment of otitis, maxillary sinusitis and pneumonia. These guidelines are in line with clinical data that showed that antibiotics do not significantly change the course of acute bronchitis, and might provide only minimal benefit compared with the risk of antibiotic use itself (Albert, 2010). However, studies showed that almost $2 / 3$ of patients in United States with acute bronchitis are treated with antibiotics with argument that they might decrease the risk of subsequent pneumonia as well as patient expectations for antibiotic prescription (Albert, 2010, Linder and Sim, 2002).

\section{Conclusion}

Results from conducted survey identified high prescription rate and use of antibiotics predominantly ceftriaxone, a third generation of cephalosporin, for pediatric and infant patients admitted in Kocani Hospital in the period 2016-2018. In the studied period decrease of cephalosporin usage was observed especially in 2018 and it was related to the increase of ampicillin use. The most frequent diagnoses were acute tonsillitis, pneumonia without complications and acute bronchitis. Treatment of patients diagnosed with acute tonsillitis in 2016-2017 was mostly based on ceftriaxone, while in 2018 ampicillin prevailed. In the case of pneumonia without complications ceftriaxone was also most commonly used antibiotic although WHO recommends it as a second line treatment when the first line treatment fails. When acute bronchitis was in question, ceftriaxone and cefotaxime were most used antibiotics contrary to official recommendations and evidences based on clinical data. So, it is foreseeable to conclude that there is urgent need for restrictive and educational measures i.e. to strength the surveillance and monitoring of antibiotic prescription and usage and hence to promote awareness for rational use of antibiotics on all health-care levels.

\section{References}

Albert, R.H., 2010. Diagnosis and treatment of acute bronchitis. American family physician 82(11), 1345-1350.

Armand-Lefevre, L., Angebault, C., Barbier, F., Hamelet, E., Defrance, G., Ruppe, E., Bronchard, R., Lepeule, R., Lucet, J.C., El Mniai, A., Wolff, M., Montravers, P., Plesiat, P., Andremont, A., 2013. Emergence of imipenem-resistant gram-negative bacilli in intestinal flora of intensive care patients. Antimicrob. Agents Chemother. 57, 1488-1495. Available at: https://doi.org/10.1128/AAC.01823-12.

Arnold, H.M., Micek, S.T., Skrupky, L.P., Kollef, M.H., 2011. Antibiotic stewardship in the intensive care unit. Semin. Respir. Crit. Care. Med. 32, 215-227.

Bergmans, D.C, Bonten, M.J., Gaillard, C.A., Van Tiel, F.H., Van der Gees, S., De Leeuw, P.W., Stobberingh, E.E., 1997. Indications for antibiotic use in ICU patients: a oneyear prospective surveillance. J. Antimicrob. Chemother. 1997, 39, 527-535. Available at: https://doi.org/10.1093/jac/39.4.527.

Goldmann, D.A., Weinstein, R.A., Wenzel, R.P., Tablan, O.C., Duma, R.J., Gaynes, R.P., Schlosser, J., Martone, W.J., 1996. Strategies to prevent and control the emergence and spread of antimicrobial-resistant microorganisms in hospitals, A challenge to hospital leadership. J.A.M.A. 275, 234-240. Available at: https://doi.org/10.1001/jama.1996.03530270074035.

Kollef, M.H., Fraser, V.J., 2001. Antibiotic resistance in the intensive care unit. Ann. Intern. Med. 2001, 134, 298-314. Available at: https://doi.org/10.7326/0003-4819-134-4200102200-00014.

Kollef, M.H., 2001. Optimizing antibiotic therapy in the intensive care unit setting. Crit. Care 5, 189-195. Available at: https://doi.org/10.1186/cc1022.

Landman, D., Quale, J.M., Mayorga, D., Adedeji, A., Vangala, K., Ravishanka, J., Flores, C., Brooks, S., 2002. Citywide clonal outbreak of multiresistant Acinetobacter baumannii and Pseudomonas aeruginosa in Brooklyn, NY: the preantibiotic era has returned. Arch. Intern. Med. 162, 1515-1520. Available at:

https://doi.org/10.1001/archinte.162.13.1515. 
Laxminarayan, R., Duse, A., Wattal, C., Zaidi, A.K., Wertheim, H.F., Sumpradit, N., Vlieghe, E., Hara, G.L., Gould, I.M., Goossens, H., Greko, C., So, A.D., Bigdeli, M., Tomson, G., Woodhouse, W., Ombaka, E., Peralta, A.Q., Qamar, F.N., Mir, F., Kariuki, S., Bhutta, Z.A., Coates, A., Bergstrom, R., Wright, G.D., Brown, E.D., Cars, O., 2013. Antibiotic resistance - the need for global solutions. Lancet Infect. Dis. 13, 1057-1098. Available at: https://doi.org/10.1016/S1473-3099(13)70318-9.

Leuthner, K.D., Doern, G.V., 2013. Antimicrobial stewardship programs. J. Clin. Microbiol. 51, 3916-3920. Available at: https://doi.org/10.1128/JCM.01751-13.

Linder, J.A. and Sim, I., 2002. Antibiotic treatment of acute bronchitis in smokers: a systematic review. Journal of general internal medicine 17(3), 230-234. Available at: https://doi.org/10.1046/j.1525-1497.2002.10405.x.

Lipsitch, M., Bergstrom, C.T., Levin, B.R., 2000. The epidemiology of antibiotic resistance in hospitals: paradoxes and prescriptions. Proc. Natl. Acad. Sci. USA 97, 1938-1943. Available at: https://doi.org/10.1073/pnas.97.4.1938.

Lodha, R., Kabra, S.K., Pandey, R.M., 2013. Antibiotics for community-acquired pneumonia in children. Cochrane Database of Systematic Reviews Issue 6. Art. No.: CD004874. Available at: https://doi.org/10.1002/14651858.CD004874.pub4.

MacDougal, C., Polk, R.E., 2005. Antimicrobial stewardship programs in health care systems. Clin. Microbiol. Rev. 18, 638-656. Available at: https://doi.org/10.1128/CMR.18.4.638-656.2005.

Malhotra-Kumar, S., Lammens, C., Coenen, S., Van Herck, K., Goossens, H., 2007. Effect of azithromycin and clarithromycin therapy on pharyngeal carriage of macrolide-resistant streptococci in healthy volunteers: a randomised, double-blind, placebo-controlled study. Lancet 369, 482-490. Available at: https://doi.org/10.1016/S0140-6736(07)60235-9.

McGowan, J.E., 1983. Antimicrobial resistance in hospital organisms and its relation to antibiotic use. Rev. Infect. Dis. 5, 1033-1048. Available at: https://doi.org/10.1093/clinids/5.6.1033.

Paterson, D.L., 2006. The role of antimicrobial management programs in optimizing antibiotic prescribing within hospitals. Clin. Infect. Dis. 42, S90-S95. Available at: https://doi.org/10.1086/499407.

Porta, A., Hsia, Y., Doerholt, K., Spyridis, N., Bielicki, J., Menson, E., Tsolia, M., Esposito, S., Wong, I.C., Sharland, M., 2012. Comparing neonatal and paediatric antibiotic prescribing between hospitals: a new algorithm to help international benchmarking. Journal of antimicrobial chemotherapy 67(5), 1278-1286. Available at: https://doi.org/10.1093/jac/dks021.

Quaak, C.H., Cové, E., Driessen, G.J., Tramper-Stranders, G.A., 2018. Trends in paediatric inpatient antibiotic therapy in a secondary care setting. European journal of pediatrics 177(8), 1271-1278. Available at: https://doi.org/10.1007/s00431-018-3185-z.

Rice, L.B., 2008. The Maxwell Finland Lecture: For the duration-rational antibiotic administration in an era of antimicrobial resistance and Clostridium difficile. Clin. Infect. Dis. 46, 491-496. Available at: https://doi.org/10.1086/526535.

Roberts, J.A., Paul, S.K., Akova, M., Bassetti, M., De Waele,
J.J., Dimopoulos, G., Kaukonen, K.M., Koulenti, D., Martin, C., Montravers, P., Rello, J., Rhodes, A., Starr, T., Wallis, S.C., Lipman, J., 2014. Defining antibiotic levels in intensive care unit patients: are current beta-lactam antibiotic doses sufficient for critically ill patients? Clin. Infect. Dis. 58, 1072-1083. Available at: https://doi.org/10.1093/cid/ciu027.

Shlaes, D.M., Gerding, D.N., John, J.F., Jr Craig, W.A., Bornstein, D.L., Duncan, R.A., Eckman, M.R., Farrer, W.E., Greene, W.H., Lorian, V., Levy, S., McGowan, J.E. Jr Paul, S.M., Ruskin, J., Tenover, F.C., Watanakunakorn, C., 1997. Society for Healthcare Epidemiology of America and Infectious Diseases Society of America joint committee on the prevention of antimicrobial resistance: guidelines for the prevention of antimicrobial resistancein hospitals. Clin. Infect. Dis. 25, 584-599. Available at: https://doi.org/10.1086/513766.

Sievert, D.M., Ricks, P., Edwards, J.R., Schneider, A., Pate, J., Srinivasan, A., Kallen, A., Limbago, B., Fridkin, S., 2013. Antimicrobial-resistant pathogens associated with healthcare-associated infections: summary of data reported to the national healthcare safety network at the centers for disease control and prevention. Infect. Control. Hosp. Epidemiol. 34, 1-14. Available at: https://doi.org/10.1017/ice.2016.174.

Sviestina, I., Mozgis, D., 2014. Antimicrobial usage among hospitalized children in Latvia: A neonatal and pediatric antimicrobial point prevalence survey. Medicina 50(3), 175-181. Available at: https://doi.org/10.1016/j.medici.2014.08.005.

Thomas, J.K., Forrest, A., Bhavnani, S.M., Hyatt, J.M., Cheng, A., Ballow, C.H., Schentag, J.J., 1998. Pharmacodynamic evaluation of factors associated with the development of bacterial resistance in acutely ill patients during therapy. Antimicrob. Agents. Chemother. 42, 521-527. Available at: https://doi.org/10.1128/AAC.42.3.521.

Tong, N., 2013. Background Paper 6.22 Pneumonia. Priority Medicines for Europe and the World "A Public Health Approach to Innovation". Available at: https://www.who.int/medicines/areas/priority_medicines/ BP6_22Pneumo.pdf, Last accessed: May, 2019.

WHO Guidelines Approved by the Guidelines Review Committee, 2012. Recommendations for Management of Common Childhood Conditions: Evidence for Technical Update of Pocket Book Recommendations: Newborn Conditions, Dysentery, Pneumonia, Oxygen Use and Delivery, Common Causes of Fever, Severe Acute Malnutrition and Supportive Care. Geneva: World Health Organization. Available at:

https://apps.who.int/iris/bitstream/handle/10665/44774/97 89241502825_eng.pdf;jsessionid=211EFF0110A0661216 FE614088C72DA4? sequence $=1$.

Zec, S.L., Selmanovic, K., Andrijic, N.L., Kadic, A., Zecevic, L., Zunic, L., 2016. Evaluation of drug treatment of bronchopneumonia at the pediatric clinic in Sarajevo. Medical Archives 70(3), 177-181. Available at: https://doi.org/10.5455/medarh.2016.70.177-181.

Zillich, A.J., Sutherland, J.M., Wilson, S.J., Diekema, D.J., Ernst, E.J., Vaughn, T.E., Doebbeling, B.N., 2006. Antimicrobial use control measures to prevent and control. Infect. Control. Hosp. Epidemiol. 27(10), 1088-1095. Available at: https://doi.org/10.1086/507963. 


\title{
Резиме
}

\section{Употреба и управување со антибиотици во Општа болница Кочани - годишен извештај}

\author{
Нада Илиева, Милена Николова, Донка Панков, Маја Симоноска Црцаревска, \\ Кристина Младеновска, Душко Шалабалија, Љубица Михаилова, \\ Олга Гигопулу, Марија Главаш Додов*
}

\author{
Фармацевтски факултет, Универзитет „Св. Кирил и Методиј”, Мајка Тереза 47, \\ 1000 Скопје, Р. Северна Македонија
}

\begin{abstract}
Клучни зборови: пропишување на антибиотици, употреба на антибиотици, педијатарски оддели, годишен извештај
\end{abstract}

Целта на студијата беше да се добие детален увид во трендовите на потрошувачка на антибиотици во тригодишниот период (2016-2018 година) во болницата во Кочани, да се идентификуваат најчесто пропишаните антибиотици и да се утврди дали третманот на дадената дијагноза е во согласност со официјалните упатства. Истражувањето ги опфати сите деца и новороденчиња примени на педијатриското одделение. Податоците на пациентите вклучуваат: пол, возраст, дијагноза, користен антибиотик и дозирање. Поголемиот дел од примените пациенти биле во возрасна група од 0-1 година (27,48\%, 25,94\% и 30,77\% за 2016, 2017 и 2018 година, соодветно), потоа следува возрасната група од 1-2 години (20,86\%, 22,0\% и 23,83\% за 2016, 2017 и 2018 година, последователно) и возрасната група 2-3 години (16,06\%, 16,1\% и 14,63\% за 2016, 2017 и 2018 година, последователно). Во периодот од 2016-2018 година најчеста дијагноза била акутен тонзилитис, утврден кај 21\% од пациентите, потоа следува пневмонија без компликации, кај 18\% од пациентите и акутен бронхитис кај $16 \%$ од пациентите. Резултатите од спроведеното истражување покажаа висока стапка на пропишување и употреба на антибиотици, претежно цефтриаксон (82,58\%, 81,05\% и 50,85\% во 2016, 2017 и 2018 година, соодветно) спротивно на официјалните препораки и докази засновани врз клиничките податоци за третман на соодветните дијагнози. Добиените резултати од истражувањето укажуваат дека постои итна потреба од примена на рестриктивни и едукативни мерки, т.е. да се зајакне надзорот и следењето на пропишувањето и употребата на антибиотици и да се зголеми свесноста за рационална употреба на антибиотици на сите нивоа на здравствената заштита. 
